\title{
Fuzzy Pedicel: A New Postharvest Disease of Banana
}

Tara L. Tarnowski, José M. Pérez-Martínez, and Randy C. Ploetz, Department of Plant Pathology, Tropical Research and Education Center, University of Florida, Homestead 33031-3314

\begin{abstract}
Tarnowski, T. L., Pérez-Martínez, J. M., and Ploetz, R. C. 2010. Fuzzy pedicel: A new postharvest disease of banana. Plant Dis. 94:621-627.

Banana fruit of the Cavendish subgroup, Musa acuminata, are significant international commodities. Recently, a transnational company attempted to develop single fruit (fingers) as a product in the United States. In the summer of 2007, an unknown problem developed (hereafter, "fuzzy pedicel"), wherein mats of fluffy gray to white mycelial mats covered large portions of the pedicel surface of fruit when they were packed in gas-permeable containers. Fungi from two genera sporulated on examined pedicels: Sporothrix, which occurred on $72 \%$ of the affected pedicels, and Fusarium (6\%); other fungi were sterile. From pedicel tissue, four genera of fungi were isolated on potato dextrose agar: Sporothrix and Fusarium and, less frequently, Pestalotiopsis and Nigrospora. Based on alignment with internal transcribed spacer and $\beta$-tubulin sequence data, the Sporothrix isolates were closely related to those in an environmental Ophiostoma/Sporothrix clade that contains Sporothrix stylites, S. humicola, and S. pallida but not the human pathogen $S$. schenkii. Based on EF1 $\alpha$ gene sequences, four species in the Gibberella fujikuroi species complex (Fusarium proliferatum, F. pseudocircinatum, F. sacchari, and $F$. verticillioides) and two unnamed taxa in the $F$. incarnatum-equiseti species complex were identified. After artificial inoculation, representative Sporothrix and Fusarium isolates caused fuzzy pedicel symptoms on fruit of 'Grand Nain,' a commercial Cavendish cultivar. Fuzzy pedicel development was inhibited at $14^{\circ} \mathrm{C}$ (temperature at which fruit are shipped) but developed at $25^{\circ} \mathrm{C}$ (temperature at which fruit are marketed). Sporothrix isolates were insensitive to thiophanate-methyl fungicide in vitro and when used to treat pedicel surfaces prior to inoculation. Thus, it appears that benzimidazole fungicides would be ineffective as postharvest treatments for this problem. In summary, a new postharvest disease of banana, fuzzy pedicel, affects single fingers. It is caused by Sporothrix sp. and several species of Fusarium. Sporothrix spp. and F. pseudocircinatum have not been reported previously on banana.
\end{abstract}

Banana (Musa spp.) is a valuable food and export commodity in the tropics. Only $15 \%$ of these fruit are traded internationally but they have an annual value of approximately $\$ 5$ billion.

Fruit of the Cavendish cultivars dominate the international banana trade. They possess desirable agronomic and organoleptic characteristics but are fragile and highly perishable (27). To ensure that a high-quality product with a long shelf life reaches terminal markets, these climacteric fruit go through a series of postharvest steps. Initially, "hands" (fused sets of a dozen or so fingers) of fruit are cut from harvested "bunches" (infructescences in which hands are distributed vertically along a peduncle), washed, and treated with a fungicide. Hands are then packed in padded cardboard boxes, moved in refrig-

Corresponding author: R. C. Ploetz E-mail: kelly12@ufl.edu

The e-Xtra logo stands for "electronic extra" and indicates that Figure 1 appears in color in the online edition.

Accepted for publication 4 February 2010.

doi:10.1094/PDIS-94-5-0621

(C) 2010 The American Phytopathological Society erated containers to ports, and transported in ships in which temperature, humidity, and gas environments are controlled (26).

The exposed, wounded area where hands were attached to the peduncle (i.e., the crown) is a significant site for pathogen invasion. Different postharvest rots develop at the wound site, depending on production region, season, and the responsible pathogens $(12,26,29)$. Colletotrichum musae, the cause of anthracnose, is most important, but several other fungi can be significant, including, alphabetically: Acremonium spp., Cephalosporium spp., Chalara paradoxa (syn.: Thielaviopsis paradoxa; teleomorph: Ceratocystis paradoxa), Deightoniella torulosa, Fusarium concentricum, F. semitectum, F. verticillioides, Lasiodiplodia theobromae (teleomorph: Botryospaeria rhodina), Musicillium theobromae (syn.: Verticillium theobromae), and Nigrospora sphaerica $(7,8,10-14,18,24,26,29,31)$.

Banana export companies experiment with new ways in which this fruit could be marketed and utilized by consumers. For example, undersized banana fruit have been sold as "lunch-box" fruit and banana juice has become an ingredient in some tropical fruit juice blends. To this end, Chiquita Fresh North America L.L.C. recently investigated single fingers, rather than complete hands, as consumer products. Fingers were cut from hands of fruit that were shipped to Port Everglades, FL, such that the crown area was removed while retaining as much pedicel as possible. Fingers were then packed in gaspermeable plastic packages for shipment.

The present article describes a new postharvest disease of banana, "fuzzy pedicel," that was observed during the development of the single-finger product. In general, light-gray lawns of mycelium were observed on the surface of the cut end of pedicels of Cavendish fruit after fingers were placed in plastic shipping packages (Fig. 1). Although affected pedicels usually did not necrose, the fungal growth was judged a significant aesthetic obstacle in the development of the product. We report the identity and frequency of isolation of different fungi from affected pedicels, indicate which fungi cause fuzzy pedicel, and describe the impacts of temperature and fungicide treatment on the disease's development.

\section{MATERIALS AND METHODS}

Identification and frequency of isolates associated with fuzzy pedicels. In total, 32 symptomatic banana fruit from 16 consignments of prepackaged Cavendish banana were inspected to determine the species of fungi that colonized the cut surface of pedicels. Fruit were cultivated in two locations in Guatemala. Tissues from 2 and $4 \mathrm{~mm}$ below the cut surfaces were also examined to determine whether fungi colonized pedicels internally. Tissue pieces were surface disinfested, plated on potato dextrose agar (PDA) amended with ampicillin and streptomycin, and viewed after 7 days at room temperature. Fungi were identified with macroscopic and microscopic characters $(1,15)$.

DNA extraction and sequencing. Isolates of the most commonly recovered fungal taxa were grown for 3 to 5 days in

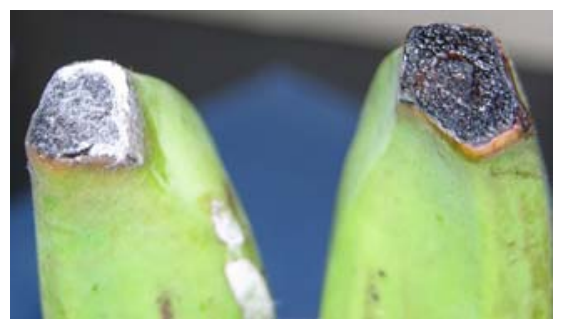

Fig. 1. Pedicel surfaces of 'Grand Nain' fruit inoculated (left) and not inoculated (right) with an isolate of Sporothrix sp. 
potato dextrose broth at room temperature on a shaker at approximately $80 \mathrm{rpm}$. Mycelia were harvested and triple rinsed with sterile deionized water and dried on sterile filter paper. DNA was extracted using a simple DNA prep protocol from the University of Wisconsin Biotechnology Center. Briefly, mycelium was ground in 500 $\mu \mathrm{l}$ of Shorty DNA Extraction Buffer $(0.2 \mathrm{M}$ Tris- $\mathrm{HCl}, \mathrm{pH} 9.0 ; 0.4 \mathrm{M} \mathrm{LiCl} ; 25 \mathrm{mM}$ EDTAll and $1 \%$ sodium dodecyl sulfate) and incubated at $68^{\circ} \mathrm{C}$ for $10 \mathrm{~min}$. Tissue was centrifuged at 14,000 rpm for $5 \mathrm{~min}$, $400 \mu \mathrm{l}$ of the supernatant was transferred to a new tube, and the DNA was precipitated with $400 \mu \mathrm{l}$ of $99 \%$ isopropanol. The tubes were centrifuged for $10 \mathrm{~min}$ at $14,000 \mathrm{rpm}$ and the supernatant was decanted. The DNA pellets were air dried for $5 \mathrm{~min}$, then resuspended in $400 \mu \mathrm{l}$ of TrisEDTA buffer for $30 \mathrm{~min}$ at room temperature; $2 \mu \mathrm{l}$ of DNA was used in polymerase chain reaction (PCR) reactions.

For Sporothrix isolates, the internal transcribed spacer (ITS)1-5S-ITS2 ribosomal region and the $\beta$-tubulin gene region were amplified by PCR in $50-\mu$ reactions containing $38.25 \mu \mathrm{l}$ of sterile distilled, deionized water, $6.5 \mu \mathrm{l}$ of ThermoPol Reaction Buffer (New England Biolabs, Ipswich, MA), $1 \mu \mathrm{l}$ of $10 \mathrm{mM}$ dNTP mix (New England Biolabs), $0.25 \mu \mathrm{l}$ of Taq DNA polymerase $($ concentration $=5,000$ units $/ \mathrm{ml}), 1$ $\mu \mathrm{l}$ each of $15 \mu \mathrm{M}$ primers, and $2 \mu \mathrm{l}$ of DNA template using the following primers: ITS1 (5) and ITS4 (30) for ITS, and T1 and Btb2 (6) for $\beta$-tubulin. Standard cycling parameters with a $55^{\circ} \mathrm{C}$ annealing temperature were used. To sequence the EF1 $\alpha$ locus of the Fusarium isolates, identical PCR reactions were carried out using primers EF-1 and EF-2 (17). PCR products were cleaned with ExoSap and sequenced on an ABI-3730-XL sequencer at the University of Florida National Center for Biotechnology Information Facility. Sequences were identified to species level by insertion into alignments with previously published GenBank sequences in the species complexes in which the taxa belong (Table 1). Fusarium isolates were identified to species level using alignment of EF1 $\alpha$ sequences with those published in GenBank. Maximum parsimony analyses, using default parameters in MEGA v 4.0.1 (28) and 500 bootstrap replicates, were used to infer phylogenetic relationships of the Sporothrix isolates to previously described Sporothrix or Ophiostoma spp.

To confirm that the morphology of the above isolates corresponded to identities that were based on DNA sequences, their colony morphology, conidia, and conidiophores were examined. Fusarium isolates were grown on banana leaf agar $(2 \%$ water agar with sterile banana leaf pieces on surface) and PDA for 7 to 10 days. Colony color, conidium shape, number of septa, and presence of mono- and polyphialides were then recorded and compared with those published for the corresponding species based on EF1 $\alpha$ sequence data (15). Sporothrix isolates were grown on malt extract agar, and colony characteristics, as well as conidium shape and size, and conidiophore morphology were compared with those described for Sporothrix humicola, S. pallides, and $S$. stylites, three species that were most closely related to the pedicel isolates based on the ITS phylogeny (3).

Reproduction of fuzzy pedicel symptoms and affects of temperature and fungicide on Fusarium and Sporothrix isolates. Mature fruit of 'Grand Nain', a Cavendish cultivar, were harvested from an experimental plot at the Tropical Research and Education Center in which fungicides had not been used. For the fungicide sensitivity assay, individual fingers were removed from hands and the associated pedicel was dipped in OHP 6672 (50\% thiophanate methyl; OHP, Inc., Mainland, PA) at $1.04 \mathrm{~g} / \mathrm{liter}$ (= label rate of 14 oz./100 gal.) or a water control and allowed to dry. Fruit were inoculated by submerging pedicels into suspensions of $10^{5}$ conidia $\mathrm{ml}^{-1}$ of the indicated isolates in Table 1. The fruit were incubated in moist plastic bags at $25^{\circ} \mathrm{C}$. Each treatment (all isolate-fungicide combinations) was replicated on five fingers in each of two experiments, and banana fruit were monitored for 14 days for mycelial growth on the cut pedicel surface. Incidence was recorded for treatments as the proportion of the five fruit that exhibited mycelial growth (i.e., fuzzy pedicels). The number of days for fuzzy pedicel development was recorded and growth of the inoculated isolated was confirmed microscopically. To determine whether isolates colonized pedicels internally, tissue was taken $4 \mathrm{~mm}$ below the cut surface, surface disinfested, and plated on antibiotic-amended PDA; plates were monitored for 7 days for growth of the inoculated isolate. The experimental design was a split plot in a randomized complete block design (RCBD) with fungicide being the main plot and isolate the subplot; the two repetitions of the experiment were treated as blocks. Analysis of variance (ANOVA) was performed on incidence data, internal colonization of pedicels, and number of days until sign development. Mean separation for dependent variables (fungicide treatment and isolate) was performed using Fisher's least significant difference (LSD)

Table 1. Identification of Sporothrix and Fusarium isolates recovered from fuzzy pedicel-affected banana fruit

\begin{tabular}{|c|c|c|c|c|c|c|}
\hline \multicolumn{2}{|l|}{ Taxa or isolate } & \multirow[b]{2}{*}{ Locus sequenced $^{\mathrm{z}}$} & \multirow[b]{2}{*}{ GenBank accession no. } & \multirow[b]{2}{*}{ Species } & \multicolumn{2}{|c|}{$\begin{array}{l}\text { Frequency of pedicel } \\
\text { recovery }(\%)\end{array}$} \\
\hline Accession $^{x}$ & Equivalent no..$^{y}$ & & & & Surface & Subsurface \\
\hline Sporothrix sp. & $\ldots$ & $\ldots$ & $\cdots$ & $\ldots$ & 71.9 & 71.9 \\
\hline$*$ Spor1 & $\ldots$ & ITS, $\beta$-tub & GU377301, GU045499 & Sporothrix sp. & $\ldots$ & $\ldots$ \\
\hline$*$ Spor3 & $\ldots$ & ITS, $\beta$-tub & GU377300, GU045500 & Sporothrix sp. & $\ldots$ & $\ldots$ \\
\hline Spor4 & $\ldots$ & ITS, $\beta$-tub & GU377302, GU045502 & Sporothrix sp. & $\ldots$ & $\ldots$ \\
\hline GFSC & & $\ldots$ & $\ldots$ & $\ldots$ & 3.1 & 9.4 \\
\hline$* \mathrm{GF} 1$ & NRRL 54198, M-8893 & $\mathrm{EF} 1 \alpha$ & GU377296 & Fusarium sacchari & $\ldots$ & $\ldots$ \\
\hline$* \mathrm{GF} 2$ & NRRL 54199, M-8894 & $\mathrm{EF} 1 \alpha$ & GU377299 & $F$. verticillioides & $\ldots$ & $\ldots$ \\
\hline$* \mathrm{GF} 3$ & NRRL 54200, M-8895 & $\mathrm{EF} 1 \alpha$ & GU377298 & F. pseudocircinatum & $\ldots$ & $\ldots$ \\
\hline$* \mathrm{GF} 4$ & NRRL 54201, M-8896 & $\mathrm{EF} 1 \alpha$ & GU377297 & F. proliferatum & $\ldots$ & $\ldots$ \\
\hline FIESC & & $\ldots$ & $\ldots$ & $\ldots$ & 3.1 & 9.4 \\
\hline *FIESC1 & NRRL 54202, R-10098 & $\mathrm{EF} 1 \alpha$ & GU045503 & FIESC sp. 15C & $\ldots$ & $\ldots$ \\
\hline FIESC 3 & R-10100 & $\mathrm{EF} 1 \alpha$ & GU045502 & FIESC sp. 16 & $\ldots$ & $\ldots$ \\
\hline FIESC4 & $\mathrm{R}-10101$ & $\mathrm{EF} 1 \alpha$ & GU045505 & FIESC sp. 16 & $\ldots$ & $\ldots$ \\
\hline Nigrospora spp. & $\ldots$ & $\ldots$ & $\ldots$ & $\ldots$ & 0.0 & 21.9 \\
\hline Pestalotia spp. & $\ldots$ & $\ldots$ & $\ldots$ & $\ldots$ & 0.0 & 15.6 \\
\hline
\end{tabular}

${ }^{\mathrm{x}}$ Asterisk (*) indicates isolate used in artificial inoculation studies. GFSC $=$ Gibberella fujikuroi species complex and FIESC $=$ Fusarium incarnatum-equiseti species complex.

y Accessions beginning with "NRRL" are deposited in the USDA-ARS, NCAUR collection in Peoria, IL, and those beginning with an "M" or "R" are deposited at the Fusarium Research Center, Pennsylvania State University, University Park, PA. The three accessions of Sporothrix sp. have been deposited in both the Centraalbureau voor Schimmelcultures, Utrecht, The Netherlands, and the culture collection of the Forestry and Agricultural Biotechnology Institute (FABI), University of Pretoria, Pretoria, South Africa (accession nos. forthcoming).

${ }^{\mathrm{z}}$ ITS $=$ internal transcribed spacer and $\beta$-tub $=\beta$-tubulin. 
using PROC GLM in SAS (v. 9.2; SAS Institute, Cary, NC).

The temperature sensitivity assay was performed similarly to the fungicide experiment, except that no fruit were treated with fungicide. Inoculated fruit were incubated at $14^{\circ} \mathrm{C}$ (the temperature at which exported fruit are shipped) or $25^{\circ} \mathrm{C}$ (approximately room temperature), and fuzzy pedicel incidence, days to colonization, and internal colonization variables were measured and analyzed as above, with temperature as the main plot and isolate as the subplot.

In vitro temperature and fungicide studies. The effect of temperature and fungicide on mycelial growth of isolates used in fruit inoculations was evaluated in vitro. Isolates were grown on PDA in plastic petri dishes. Plugs, $5 \mathrm{~mm}$ in diameter, were taken from the edges of actively growing PDA cultures and placed in the center of $10-\mathrm{cm}$-diameter plates containing approximately $20 \mathrm{ml}$ of PDA. For temperature experiments, plates were incubated in the dark at 14 and $25^{\circ} \mathrm{C}$. Three replicates per isolate were evaluated at each temperature. The experiments were conducted twice. Radial growth measurements were initiated $24 \mathrm{~h}$ after colony growth began at the different temperatures. The experimental design was a split-plot RCBD with experiments as blocks, temperature as the main plot, and isolate as the subplot. My- celial growth rate was calculated by dividing colony radius by days of growth. ANOVAs were performed to evaluate the relationships between growth rates and temperatures among isolates.

In fungicide studies, seven fungicide concentrations of OHP $6672(0.0,0.1,0.5$. $0.75,1.0,5.0,10.0$, and $15.0 \mathrm{~g}$ a.i. liter $^{-1}$ ) were tested in vitro. Fungicide that was suspended in sterile distilled water was added to previously cooled, autoclaved PDA to give the desired concentrations. Fungicide impact on linear growth rate and the $50 \%$ effective dose $\left(\mathrm{ED}_{50}\right)$ were determined for isolates of $F$. sacchari (GF1), $F$. verticillioides (GF2), F. pseudocircinatum (GF3), F. proliferatum (GF4), the Fusa-

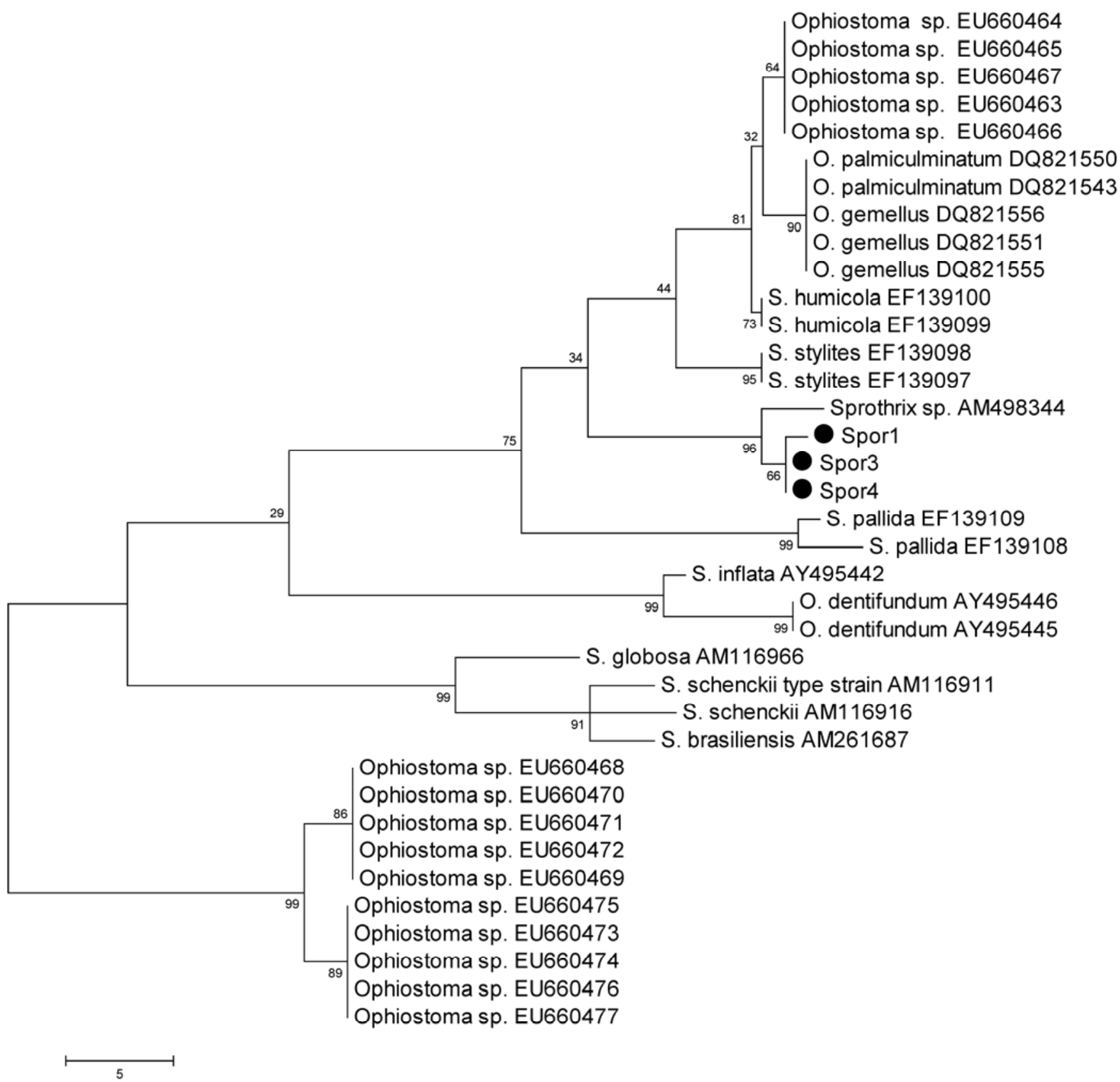

Fig. 2. One of the 1,520 most parsimonious trees from the $\beta$-tubulin data set, which included 37 isolates and 262 characters, 76 of which were parsimony informative. Tree length was $156(\mathrm{CI}=0.77, \mathrm{RI}=0.94)$. Fuzzy pedicel Sporothrix isolates are marked with a closed circle, and GenBank accession numbers appear after other isolates that were used in this analysis. Sporothrix sp. AM498344 was recently described as S. mexicana (16). 
rium incarnatum-equiseti species complex (FIESC)1, and Sporothrix sp. (SPOR1 and SPOR3). The experimental design was a split plot in an RCBD with fungicide concentration as the main plot and isolate as the subplot. The experiment was repeated twice and each experiment was treated as a block. Colonies were grown in the dark at $25^{\circ} \mathrm{C}$ and their radial growth was recorded after 7 days. Linear regressions were performed for colony growth versus fungicide concentration, and $\mathrm{ED}_{50}$ values were calcu- lated as the fungicide concentration at which mycelia growth was $50 \%$ of colonies grown on nonamended PDA. $\mathrm{ED}_{50}$ values of isolates were compared with ANOVAs. Also, percent inhibition of mycelia growth was calculated according to Edington et al. (4).

\section{RESULTS}

Identification and frequency of isolates associated with fuzzy pedicels. Based on conidium and conidiophore mor-

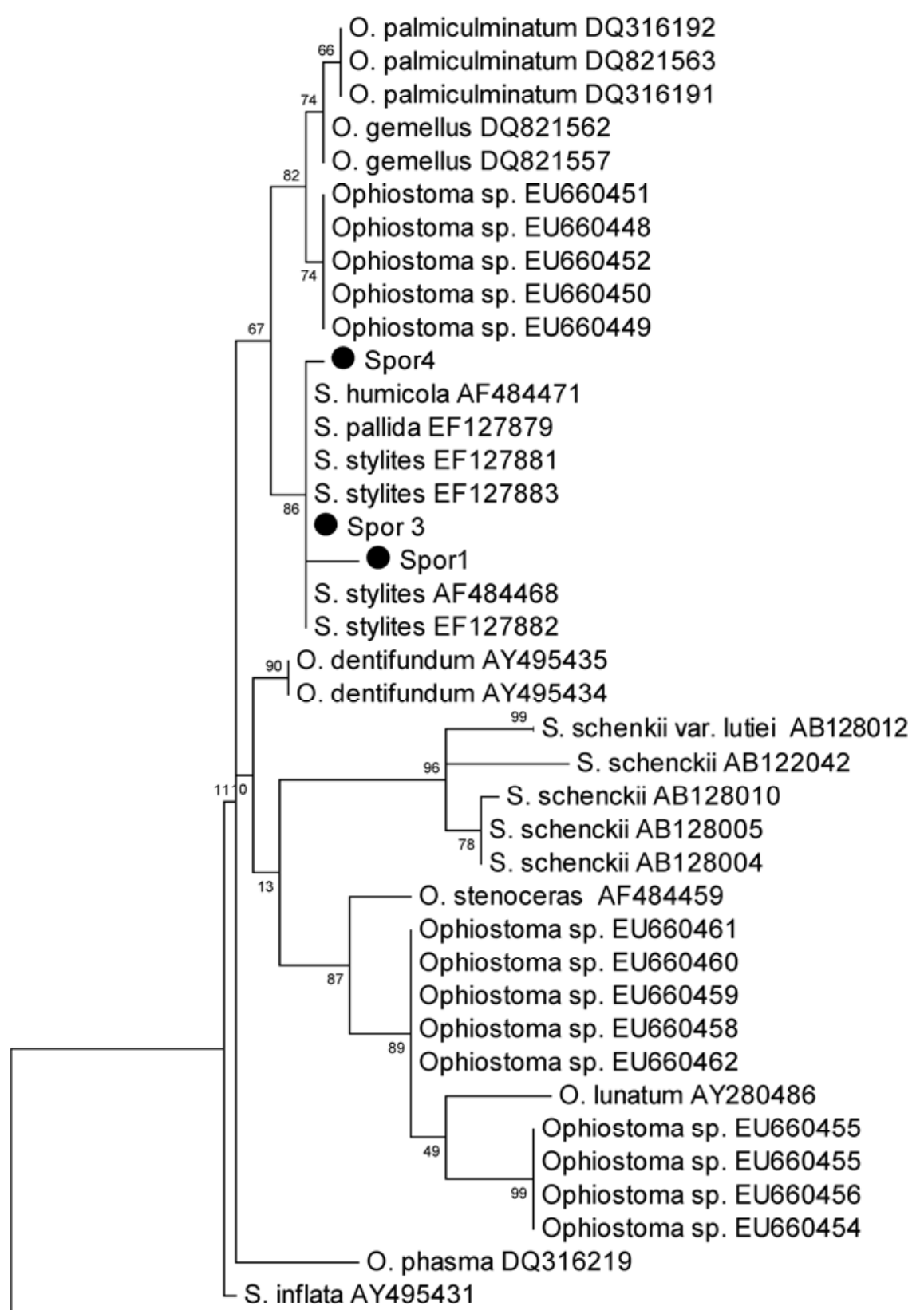

S. lignivora EF127887

${ }_{33}$ S. lignivora EF127890

Fig. 3. One of the 3,202 most parsimonious trees from the internal transcribed spacer data set, which included 43 isolates and 371 characters, 71 of which were parsimony informative. Tree length was 119 $(\mathrm{CI}=0.79, \mathrm{RI}=0.94$. Sporothrix isolates that were associated with fuzzy pedicel are marked with a closed circle, and GenBank accession numbers appear after other isolates that were used in this analysis.

phology, fungi examined directly on fuzzy pedicels were identified as Sporothrix sp. (71.8\% of fruit) and Fusarium spp. (9.4\%); the remaining samples did not sporulate and could not be identified from hyphal morphology alone. The most common genera that colonized pedicel tissue were, in descending order: Sporothrix, $71.8 \%$; Nigrospora, 21.9\%; Fusarium, 15.6\%; and Pestalotiopsis, $15.6 \%$. Due to their prevalence on the pedicel surface, representative isolates of the Fusarium and Sporothrix spp. were examined further; colony morphology and conidium and conidiophore characteristics were compared with published descriptions, and the respective EF1 $\alpha$, and $\beta$-tubulin and ITS sequences were compared with those published in GenBank (Table 1). Sequence-based identifications of the Fusarium taxa matched their morphological identities (15).

Among the Fusarium taxa, members of the FIESC were most common, followed by species in the Gibberella fujikuroi species complex (GFSC). FIESC isolates were assigned to species reported in O'Donnell et al. (19), based on EF1 $\alpha$ sequence alignment with species that were resolved in that study; two species were identified, corresponding to Fusarium spp. 15 (FIESC 1) and 16 (FIESC3 and 4) in the Incarnatum clade. FIESC 1 was used in the present inoculation studies and was placed in haplotype $15 \mathrm{C}$ based on multilocus sequence data, as described by O'Donnell et al. (19) (Stacy Sink, NCAUR United States Department of AgricultureAgricultural Research Service, Peoria IL; personal communication). FIESC 1 is deposited in the NCAUR collection as NRRL 54202. Representative accessions of the GFSC were also deposited in the NCAUR collection: F. proliferatum (GF4 = NRRL 54201), F. pseudocircinatum (GF3 $=$ NRRL 54200), $F$. sacchari $(\mathrm{GF} 1=$ NRRL 54198), and $F$. verticillioides (GF2 = NRRL 54199).

The Sporothrix $\beta$-tubulin data set included 37 accessions and 262 characters, 76 of which were parsimony informative. Maximum parsimony analysis resulted in 1,520 most parsimonious trees (MPTs) with a length of $156(\mathrm{CI}=0.77, \mathrm{RI}=0.94$; Fig. 2). The fuzzy pedicel Sporothrix isolates (SPOR1, SPOR3, and SPOR 4) had identical $\beta$-tubulin sequences and resolved into a highly supported clade ( $96 \%$ bootstrap support [BS]) with Sporothrix mexicana, isolate CBS120341, which was recovered from soil in Mexico (16) and is closely related to $S$. pallida, S. stylites, and a clade that contains S. humicola, S. stylites, Ophiostoma palmiculminatum, $O$. gemellus, and Ophiostoma protea-sedis (23).

The Sporothrix ITS data set contained 43 accessions and 371 characters, of which 71 were parsimony informative. Maximum parsimony analysis resulted in 3,202 MPTs with a length of $119(\mathrm{CI}=0.79, \mathrm{RI}=0.94$; Fig. 3). The fuzzy pedicel Sporothrix iso- 
lates had ITS sequences that differed by 1 to 3 nucleotides and resolved in a wellsupported clade $(86 \%$ BS) with S. pallida, S. humicola, and S. stylites; the former two species were described by de Meyer et al. (3).

Reproduction of fuzzy pedicel symptoms and affects of temperature and fungicide on Fusarium and Sporothrix isolates. Fungicide treatment had a significant impact on the internal colonization of pedicels and the incidence of and days to fuzzy pedicel development $(P=0.0243, P$
$<0.0001$, and $P=0.0245$, respectively). Blocks significantly affected days to sign development $(P=0$. 0035). Symptoms did not develop on fungicide-treated fruit that were inoculated with Fusarium spp. but did develop on those that were inoculated with isolates of Sporothrix sp. (Fig. 4A and B). Internal colonization of pedicels did not occur in fungicide-treated pedicels and never occurred in pedicels inoculated with Sporothrix sp. (Fig. 4B). The average days to fuzzy pedicel development was not significantly different among isolates and ranged from 6 to 9 days after inoculation for nontreated fruit.

Temperature significantly impacted fuzzy pedicel incidence and percent internal colonization of pedicels by isolates $(P$ $<0.0001$ and $P=0.0421$, respectively). Days to fuzzy pedicel development were affected significantly by blocks $(P=0$. 0327). Incidence and internal colonization were not affected significantly by the different isolates $(P=0751$ and 0.0519$)$ but were lower at 14 than $25^{\circ} \mathrm{C}$ (Fig. 5A). Fruit incubated at $14^{\circ} \mathrm{C}$ were generally not
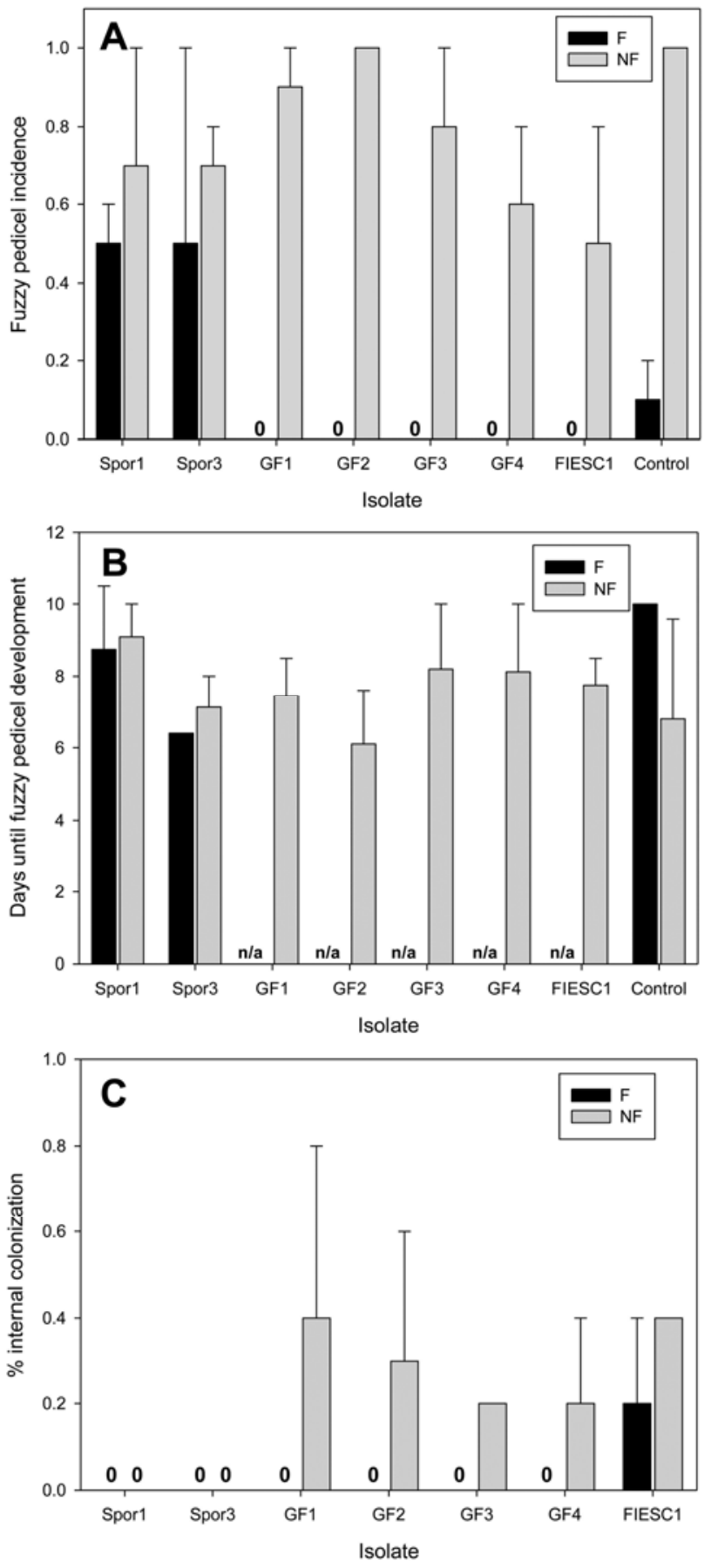

Fig. 4. Fungicide sensitivity of fuzzy pedicel isolates: A, incidence of and $\mathbf{B}$, days until fuzzy pedicel development; and $\mathbf{C}$, percent internal colonization of pedicels. A and $\mathrm{C}$ were recorded after 14 days. $\mathrm{F}=$ treated with fungicide $\left(0.52 \mathrm{~g}\right.$ of thiophanate methyl liter $\left.^{-1}\right)$ and $\mathrm{NF}=$ no fungicide. Bars $= \pm$ standard errors.
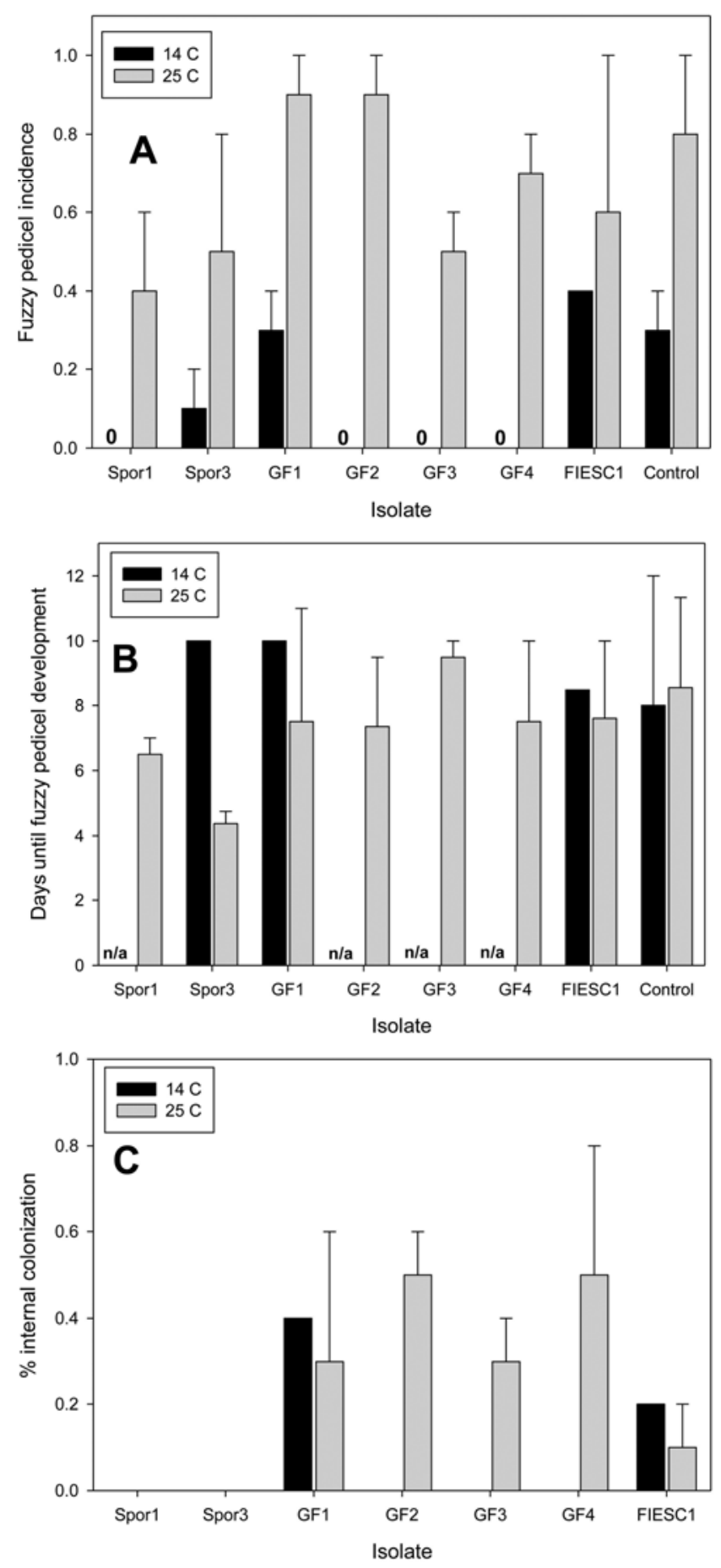

Fig. 5. Influence of temperature on $\mathbf{A}$, incidence of and $\mathbf{B}$, days until fuzzy pedicel development; and $\mathbf{C}$, percent internal colonization of pedicels. Bars $= \pm$ standard errors. 
Table 2. Effect of thiophanate methyl on the in vitro growth of fuzzy pedicel isolates ${ }^{\mathrm{x}}$

\begin{tabular}{|c|c|c|c|c|c|c|c|c|}
\hline \multirow[b]{2}{*}{ Isolate $^{y}$} & \multicolumn{7}{|c|}{ Percent inhibition of radial growth at fungicide concentration ( $\mathrm{g} \mathrm{liter}^{-1}$ ) } & \multirow[b]{2}{*}{$\mathbf{E D}_{50}(\mathrm{~g} / \mathrm{liter})^{\mathrm{z}}$} \\
\hline & 0.1 & 0.5 & 0.75 & 1.0 & 5.0 & 10.0 & 15.0 & \\
\hline GF1 (Fusarium sacchari) & 30.4 & 98 & 100 & 100 & $\ldots$ & $\ldots$ & $\ldots$ & $0.31 \mathrm{bc}$ \\
\hline GF2 (F. verticillioides) & 83.4 & 100 & 100 & 100 & $\ldots$ & $\ldots$ & $\ldots$ & $0.24 \mathrm{c}$ \\
\hline GF3 (F. pseudocircinatum) & 8.5 & 70.7 & 93.7 & 100 & $\ldots$ & $\ldots$ & $\ldots$ & $0.47 \mathrm{bc}$ \\
\hline GF4 $(F$. proliferatum $)$ & 13.45 & 83.45 & 97.8 & 98.8 & $\ldots$ & $\ldots$ & $\ldots$ & $0.42 \mathrm{bc}$ \\
\hline FIESC1 (Fusarium sp. 15C) & 52 & 66.4 & 77.7 & 80.4 & $\ldots$ & $\ldots$ & $\ldots$ & $0.56 \mathrm{ab}$ \\
\hline Spor1 & $\ldots$ & $\ldots$ & $\ldots$ & 7.9 & 16.5 & 21.2 & 34.3 & N/A \\
\hline Spor3 & $\ldots$ & $\ldots$ & $\ldots$ & 1.45 & 21.25 & 33.6 & 35.1 & N/A \\
\hline
\end{tabular}

$\mathrm{x}$ Thiophanate methyl as OHP 6672 (50\% a.i.).

${ }^{\text {y }}$ FIESC = Fusarium incarnatum-equiseti species complex.

${ }^{\mathrm{z}} \mathrm{ED}_{50}=50 \%$ effective dose. Least significant difference, $P=0.0333 ; \mathrm{N} / \mathrm{A}=$ not applicable.

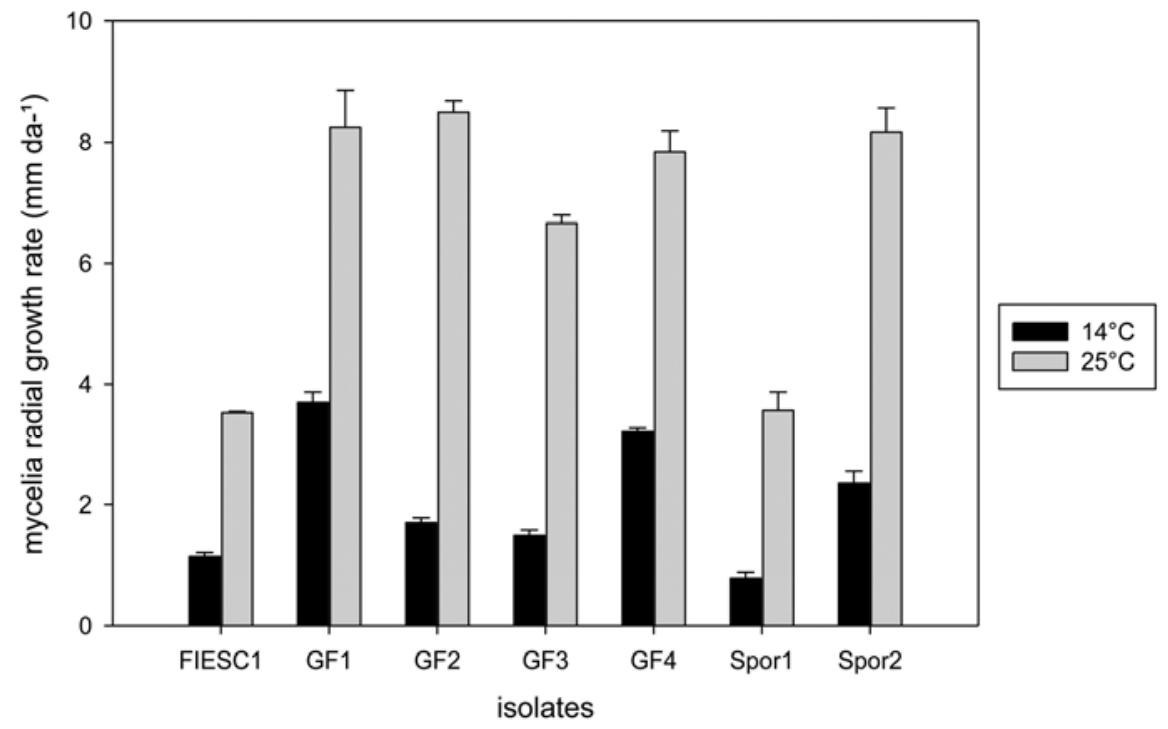

Fig. 6. Effect of temperature on in vitro radial growth of seven isolates associated with fuzzy pedicel of banana.

colonized internally, with exception of isolates FIESC1 and GF1 (F. sacchari) (Fig. 5B). Days to fuzzy pedicel development varied from 4 to 11 days for a given isolate but there was no significant isolate effect $(P=0.8638)$. Temperature did not have a consistent impact on days to fuzzy pedicel development (Fig. 5C).

In vitro temperature and fungicide sensitivity assays. Thiophanate methyl inhibited the mycelial growth of all Fusarium isolates but had a relatively minor impact on Sporothrix sp. (SPOR1 and SPOR3) (Table 2). Growth of all isolates was at least $50 \%$ less at 14 than at $25^{\circ} \mathrm{C}$ (Fig. 6).

\section{DISCUSSION}

A new disease of banana, fuzzy pedicel, has been described which develops when single fingers are packaged in gaspermeable containers. Some of the fungi that were recovered from affected pedicels had been reported previously on banana, including several species of Fusarium and N. sphaerica $(7,8,10-12,14,18,24)$. However, Sporothrix spp. and F. pseudocircinatum have not been reported previously on banana.

Sporothrix is an anamorphic genus associated with Ophiostoma teleomorphs. S. schenkii, a member of the O. stenoceras $-S$. schenkii species complex, has been associated with soil, plant material, insects, and animals; it causes sporotrichosis, a dermatological or pulmonary mycosis that is most common in South and Central America $(2,21)$. Cases of sporotrichosis most often develop from puncture wounds when handling colonized plant matter, although transmission from animals has also been implicated (22).

Although $S$. schenkii and nonpathogenic, morphologically similar Sporothrix isolates have been confused, recent systematic work distinguished four species from S. schenkii: S. stylites, S. lignivora, $S$. pallida, and S. humicola (3). Based on the $\beta$-tubulin phylogeny, it appears that the banana isolates may represent another species in a clade that contains three of the above Sporothrix spp. as well as $O$. gemellus, O. palmiculmatum, and $O$. proteasedis (23). The banana isolates were most closely related to and may be conspecific with $S$. mexicana (16). Species in this clade are saprotrophs and endophytes, and none have been identified as human pathogens. Thus, the banana isolates do not appear to pose a threat to human health. Their source and how infection of banana could be avoided are not known.
Fusarium spp. are frequent associates and causes of crown rot of banana $(9,10,14,20,26)$. The fuzzy pedicel isolates fell in the GFSC and FIESC, which contain previously reported banana pathogens. Their relatively infrequent colonization of the pedicel surface in the present study may have been due to prior treatment of the shipped fruit with fungicides or from competition from Sporothrix sp. on the pedicel surface. The two FIESC species that were recovered had $>99 \%$ EF1 $\alpha$ sequence homology with species that were recently reported in a study of clinical FIESC isolates (19); they have not been described formally.

The high relative humidity in the containers that were used to package individual fingers provided an ideal environment for fungal colonization. The high incidences of fuzzy pedicel that developed on noninoculated control fruit (Fig. 2A) indicates that this disease may be difficult to manage. In the primary survey, multiple species were isolated as internal colonizers of the pedicel, of which only Sporothrix and Fusarium spp. were identified as causes of fuzzy pedicel. Depending on the postharvest treatment of and storage conditions for fruit, other species could also cause fuzzy pedicel. For example, in control fruit that were produced in Florida and used in the fungicide/temperature study, species of Alternaria, Fusarium, and Colletotrichum were most often identified as pedicel colonizers (data not shown). This differs from the results for the fruit that were imported from Guatemala, and suggests that diverse fungi could cause fuzzy pedicel in different locations.

\section{LITERATURE CITED}

1. Barnett, H. L., and Hunter, B. B. 1972. Illustrated Genera of Imperfect Fungi, 3rd ed. Burgess Publishing Co., Minneapolis, MN.

2. De Araujo, T. D., Marques, A. C., and Kerdel, F. 2001. Sporotrichosis. Int. J. Dermatol 40:737-742.

3. De Meyer, E. M., de Beer, Z. W., Summerbell, R. C., Moharram, A. M., de Hoog, G. S., Vismer, H. F., and Wingfield, M. J. 2008. Taxonomy and phylogeny of new wood- and soilinhabiting Sporothrix species in the Ophiostoma stenoceras-Sporothrix schenkii complex. Mycologia 100:647-661.

4. Edington, L. V., Khen, K. L., and Barron, G. I. 1971. Fungitoxic spectrum of benzimidazole compounds. Phytopathology 61:42-44. 
5. Gardes, M., and Bruns T. D. 1993. ITS primers with enhanced specificity for basidiomycetes-application to the identification of mycorrhizae and rusts. Mol. Ecol. 2:113-118.

6. Glass, N. L., and Donaldson, G. C. 1995. Development of primer sets designed for use with the PCR to amplify conserved genes from filamentous Ascomycetes. Appl. Environ. Microbiol. 61:1323-1330.

7. Greene, G. L., and Goos, R. D. 1963. Fungi associated with crown rot of boxed bananas. Phytopathology 53:271-275.

8. Griffee, P. J. 1976. Pathogenicity of some fungi isolated from diseased crowns of banana hands. Phytopathol. Z. 85:206-216.

9. Jimenez, M., Huerta, T., and Mateo, R. 1997. Mycotoxin production by Fusarium species isolated from banana. Appl. Environ. Microbiol. 63:364-369.

10. Jimenez, M., Logrieco, A., and Bottalico, A. 1993. Occurrence and pathogencity of Fusarium species in banana fruits. J. Phytopathol. 137:214-220.

11. Johanson, A., and Blazquez, B. 1992. Fungi associated with banana crown rot on fieldpacked fruit from the Windward Islands and assessment of their sensitivity to fungicides thiabendazole, prochloraz and imazilil. Crop Prot. 11:79-83.

12. Jones, D. R., ed. 2000. Diseases of Banana, Abaca, and Enset. CABI Publishing. Wallingford, UK.

13. Kaiser, W. J., and Lukezic, F. L. 1966. Occurrence, sporulation and pathogenicity studies with Glomerella cingulata associated with crown rot of boxed bananas. Mycologia 58:397-405.

14. Knight, C., Cutts, D. F., and Colhoun, J. 1977.
The role of Fusarium semitectum in causing crown rot of bananas. Phytopathol. Z. 89:170176.

15. Leslie, J. F., and Sumerell, B. A. 2006. The Fusarium Laboratory Manual. Blackwell Publishing. Ames, IA.

16. Marimon, R., Cano, J., Gené, J., Sutton, D. A., Kawasaki, M., and Guarro, J. 2007. Sporothrix brasiliensis, $S$. globosa, and $S$. mexicana, three new Sporothrix species of clinical interest. J. Clin. Microbiol. 45:3198-3206.

17. O'Donnell, K., Cigelnik, E., and Nirenberg, H. I. 1998. Molecular systematics and phylogeography of the Giberella fujikuroi species complex. Mycologia 90:465-493.

18. O’Donnell, K., Kistler, H. C., Cigelnik, E., and Ploetz, R. C. 1998. Multiple evolutionary origins of the fungus causing Panama disease of banana: concordant evidence from nuclear and mitochondrial gene genealogies. PNAS 95:2044-2049.

19. O’Donnell, K., Sutton, D. A., Rinaldi, M. G., Crous, P. W., and Geiser, D. M. 2009. A novel MLST scheme reveals high genetic diversity of human pathogenic members of the Fusarium incarnatum-equiseti and $F$. chlamydosporum species complexes within the U.S. J. Clin. Microbiol. 47:3851-3861.

20. Ploetz, R. C., Thomas, J. E., and Slabaugh, W. 2003. Diseases of banana and plantain. Pages 73-134 in: Diseases of Tropical Fruit Crops. R. C. Ploetz, ed. CABI Publishing. Wallingford, UK.

21. Ramos-e-Silva, M., Vasconcelos, C., Carneiro, S., and Cestari, T. 2007. Sporotrichosis. Clin. Dermatol. 25:181-187.

22. Reed, K. D., Moore, F. M., Geiger, G. E., and Stemper, M. E. 1993. Zoonotic transmission of
Sporotrichosis: case report and review. Clin Infect. Dis. 16:384-387.

23. Roets, F., Wingfield, B. D., de Beer, Z. W., Wingfield, M. J., and Dreyer, L. L. 2010. Two new Ophiostoma species from Protea caffra in Zambia. Persoonia 24:18-28.

24. Slabaugh, W. R., and Grove, M. D. 1982. Postharvest diseases of banana and their control. Plant Dis. 66:746-750.

25. Snowden, A. L. 1990. A Color Atlas of Postharvest Diseases and Disorders of Fruits and Vegetables. Vol. 1. General Introduction and Fruits. Wolfe Scientific Publishers, London.

26. Stover, R. H. 1972. Banana, Plantain and Abaca Diseases. Commonwealth Mycological Institute, Kew, Surrey, UK.

27. Stover, R. H., and Simmonds, N. W. 1987 Bananas. 3rd ed. Longmans. London.

28. Tamura, K., Dudley J., Nei, M., and Kumar S. 2007. MEGA4: Molecular Evolutionary Genetics Analysis (MEGA) software version 4.0. Mol. Biol. Evol. 24:1596-1599.

29. Wardlaw, C. W. 1961. Banana Diseases Including Plantains and Abaca. Longmans, Green and Co Ltd., London.

30. White, T. J., Bruns, T., Lee, S., and Taylor, J. 1990. Amplification and direct sequencing of fungal ribosomal RNA genes for phylogenetics. Pages 315-322 in: PCR Protocols: A Guide to Methods and Applications. M. A. Innis, D. H. Gelfand, J. J. Sninsky, and T. J. White, eds. Academic Press, Inc., San Diego, CA.

31. Zare, R., Gams, W., Starink-Willemse, M., and Summerbell, R. C. 2007. Gibellulopsis, a suitable genus for Verticillium nigrescens, and Musicillium, a new genus for $V$. theobromae. Nova Hedwigia 85:463-489. 